\title{
THE INFLUENCE OF HOTEL WEBSITE DESIGN QUALITY, PERCEIVED EASE OF USE AND PERCEIVED USEFULNESS ON LOYALTY INTENTION
}

\author{
K. A. Bahari, D. Abdullah*, S. B. Mohd Kamal, N. R. Johari, M. S. Zulkafli \\ Faculty of Hotel and Tourism Management, Universiti Teknologi MARA, Pulau Pinang Branch, 13500 \\ Permatang Pauh, Pulau Pinang, Malaysia \\ *dahla707@ppinang.uitm.edu.my
}

\begin{abstract}
This study develops and empirically examines a theoretical model to investigate these relationships. 136 usable responses from online survey were analyzed using partial least squares - structural equation modelling (PLS-SEM) approach. The present article contributes to the existing body of knowledge by identifying the influence of website design quality on perceived ease of use, perceived usefulness and loyalty intention among hotel website users. Results indicated that website design quality, perceived ease of use, and perceived usefulness have a positive influence on loyalty intention. While perceived ease of use positively influence loyalty intention, surprisingly the influence of perceived usefulness on loyalty intention is not significant. Drawing on the empirical findings, theoretical and managerial implications were discussed and recommendation for future research are offered.
\end{abstract}

Keywords: Loyalty Intention, Website Design Quality, Perceived Ease of Use, Perceived Usefulness, Online Booking

\section{INTRODUCTION}

Lately, online booking of travel-associated products via online channels have experienced an exceptional increase rate. Because of that, the hospitality industry has adopted the Internet as an effective communication channel with its customers (Diaz \& Koutra (2013). Certainly, for businesses, a website is a useful tool to promote their products and services to generate revenues from prospective customers (Akincilar \& Dagdeviren, 2014) and retaining them. Considering the competitive environment of the industry, hotel management aims to design its website to be a dynamic marketing tool and utilize it as a means of influencing its customers' decision-making (Herrero \& San Martín, 2012). Sustaining an effective website is therefore crucial for businesses to both attract and retain loyal customers (Law et al., 2010). McMullan and Gilmore (2008) argued that loyal customers are key constituents of favorable word of mouth (WOM).

Even though previous studies have attempted to understand the factors influencing online hotel booking (Abdullah et al., 2016), there is little information about the role of website design quality in influencing customer loyalty (McMullan \& Gilmore, (2008); Rosli et al., 2016). Additionally, despite numerous studies on the evaluation of website quality (Rodzi et al., 2016), there is to date no welldeveloped model evaluating hotel websites design quality (Li et al., 2017). Specifically, little research has been performed to assess the hotel websites design quality, perceived ease of use and perceived usefulness on customers' loyalty. To fill this research gap, the current research attempts to analyze the influence of hotel website design quality, ease of use and perceived usefulness on loyalty intention. 


\section{LITERATURE REVIEW}

\section{Online Booking}

According to Parasuraman et al. (2005), in e-commerce business, online booking is one of the most important and fastest developing segment. This is because at present, the socio-economic context of tourism has been influenced by Internet usage and this will keep on inspiring extra changes (Sabiote et al., 2012). Tsai et al. (2005) also noted that in order to increase their marketing effectiveness, developing long-term competitive advantage, and gaining customer loyalty, e-commerce strategic applications are essential for the hotel industry. Annually, the quantity of online businesses is expanding, not just because of the increase within the wide variety of web primarily based retailers, additionally because of the expansion in multi-channel merchants carrying out each on-line and offline business (Hahn \& Kim, 2009). Bhatiasevi and Yoopetch (2015) has interpreted that online bookings mean making booking for services over the Internet.

Hotel companies who want to minimize costs but at the same time provide easy booking facilities for travelers often using online booking tools (OBTs) such as hotel websites, online travel agency websites and airline websites. There have been many factors affecting online booking adoption has been identified by researchers. Among them, the high rate of use is achieved when a comprehensive implementation strategy is implemented (Carlson Wagonlit Travel, 2011). In addition to booking through a desktops, customers can also use mobile phones or mobile devices connected to wireless networks to book flight tickets, hotel accommodation and other hospitality related products or services (Yang et al., 2006). According to Carlson Wagonlit Travel (2011), the adoption of online booking technology by service providers and customers in the hotel industry has recently increased due to the convenience of finding information, asking question and even making online booking.

\section{Technology Acceptance Model (TAM)}

The present research has adopted Technology Acceptance Model or TAM as the theoretical foundation to develop the theoretical model. This model is intended to illustrate and anticipate how users acceptance of information technology. Davis (1989) also states that the most important predictor in technology adoption is perceived usefulness (PU) and perceived ease of use (PEU). The scholar defined PU is defined as "the degree to which a person believes that using a particular system would enhance his or her job performance. PEU on the other hand is defined as "the degree to which a person's believes that using a particular system would be free from effort". Following TAM, an individuals' intentions can be used to predict his or her actual behavior.

\section{Customer Loyalty and Loyalty Intention}

Customer loyalty has been studied in diverse fields and contexts. The concept of loyalty generally is defined as a commitment to constantly revisit a site or repurchase an item or service from the same company, without switching to other companies (Oliver et al., 1997). This definition has been well accepted among practitioners and academics. Previous studies on Internet services discovered that customer's satisfied with a particular organization's Web services are more likely to have re-purchase intentions, recommend the Website to others and spread positive word of mouth about the Web site's services (Collier \& Bienstock, 2006). In this study, we conceptualized loyalty as behavioral loyalty (e.g., repeat purchase via positive recommendation).

As customer loyalty enables repeat purchasing behavior (Anderson \& Srinivasan, 2003), it is also capable to increase customer retention (Chirico \& Presti (2008). Oliver et al. (1997) determined that customer loyalty includes a better degree of commitment to repurchase certain products or services in the future. In the context of business benefit to business, Lam et al., (2004) examines the relationship between customer satisfactions with loyalty where loyalty is the support of online sellers and further consider is prescribing the merchant. In accordance with earlier, in the current investigation of loyalty is defined as the intended intention of visiting or using the website in the future and to consider buying from it in the future. 


\section{Website Design Quality}

According to Wakefield et al. (2004), website design quality can be defined as a technology aspect of web sites such as layout, appearance and navigation. The public sector has embarked on major website investments in an attempt to take advantage of the benefits of the Internet by extending the channels through which services are provided to its respective nationalities $(\mathrm{Ku} \&$ Chen (2015). Lehto et al. (2006) evaluated first-level convention center website according to customer's internal factors, marketing, technical and critical success factors; that is, the chosen e-tourism destination crisis communication strategy has been investigated through their websites. Theofanos and Mulligan (2004) stated that the quality of web design, including clear layout, attractive appearance, good navigation, up-to-date information, will certainly affect the tourists' behavior. In addition, high-quality website demonstrates the government's capability and its sincere interest in its travelers. Hence, based on above discussion, we believe that website design quality has significant influence on perceived ease of use and perceived usefulness of hotel booking website. For that reason, we offer the following hypotheses:

Hypothesis 1: Website design quality has a positive influence on loyalty intention

Hypothesis 2: Website design quality has a positive relationship with perceived ease of use

\section{Perceived Usefulness}

Davis (1989) defined perceived usefulness as "the degree to which a person believes that using a particular system would enhance his or her job performance". The scholar also stated that perceived usefulness has a positive influence on behavioral intention. This relationship is supported by numerous recent studies (Bhatiasevi and Yoopetch, 2015). For instance, consumer of online health services highlighted the importance of perceived usefulness both at the initial and latter stages of technology usage (Mou et al., 2016).

In the context of online booking, perceived usefulness refers to the Internet users feeling that using online booking is useful in making online reservations or online payments. Perceived usefulness can be one of the determinants to predict whether or not they will use online booking (Abdullah et al., 2017). The effect of perceived usefulness of the online booking technology on usage intention is more than the effect of perceived ease of use (Kucukusta et al., 2015). Thus, the scholar suggested that functionality, efficiency and effectiveness of the online booking technology are more important than its ease of use. In contrast, perceived ease of use has no significant effect on perceived usefulness Pai and Yeh (2014). Hence, we offer the following hypotheses:

Hypothesis 3: Website design quality has a positive influence on online perceived usefulness

Hypothesis 4: Perceived ease of use has positive influence on loyalty intention

Hypothesis 5: Perceived usefulness has a positive relationship on loyalty intention

\section{METHODOLOGY}

Sample and Data Collection

Collection of data was carried out from hotel customers who had experienced visiting hotel website for at least once for the last 12-month period from the date of data collection. A self-administered survey approach was used to collect the data through online survey tool. The survey respondents were invited to participate in the study through e-mail. Their e-mail addresses were obtained from hotel customers' database. Only those who have agreed to share their contact information were obtained. To participate in the study, the respondents were asked to click on a link to online survey platform provided in the email. Google Form was used as the online survey platform. The online survey questionnaires were attached with cover letter to inform respondents about the aims of the study. The respondents were reminded that their participation was on voluntary basis and they can withdraw from the study at any time. Definitions of the keys terms used in the questionnaires were also given. Most importantly, two screening questions were given in the beginning of the questionnaire to ensure the respondents were qualified to answer the survey questions. First, the respondents must be a Malaysian resident. Second, the respondent must have visited any hotel website for the past 12-month prior to the survey. Prior to final data collection, the questionnaires were pilot tested. 30 working adults from various organization were invited to participate in the pilot study. The pilot study showed that the survey items were reliable. Therefore, no other amendments made on the survey questionnaires. Out of 521 invitation emails sent, only 136 responded ( $26 \%$ response rate) by answering the online survey completely. Out of the 136 respondents, $46.3 \%$ were male and $53.7 \%$ were female. Majority of the respondents were in the middle age group ranging from 19 and 45 years old $(91.3 \%)$. Bachelor degree holders represent $38.2 \%$ and majority of respondent are employed with $49.3 \%$. 
Based on summary, $41.2 \%$ of respondents had a monthly gross income less than RM2,500. Lastly, the respondents were Malay (58.1\%), Chinese (21.3\%), Indian (13.2\%) and others $(7.4 \%)$.

\section{Measures}

Data was gathered by using questionnaires. Measurement items were adapted from various literature. A 7-point Likert-type scale was used where 1 mean "strongly disagree" and 7 mean "strongly agree." The questionnaires were designed based on a multiple item measurement scale adapted from previous research namely $\mathrm{Ha}$ and Im (2012) for website design quality, Kim and Niehm (2009) for perceived ease of use, Koufaris (2002) for perceived usefulness, Kim and Niehm (2009) for loyalty intention. Prior to final survey, the questionnaires were reviewed by two academic scholars in hospitality management to establish content validity.

\section{RESULTS AND DISCUSSION}

Measurement Model Estimation: The research hypotheses were tested by using a Partial Least Squares (PLS) approach. SmartPLS software version 3.2.6 were used. First, the measurement estimation for all constructs was checked for reliability, convergent validity and discriminant validity. Table 1 was presents the results of the measurement model. It was found that all loadings were higher than the threshold level of 0.7. The average variance extracted (AVE) of all constructs exceeded 0.5 . The composite reliability (CR) were all higher than 0.7 (Hair et al., 2017). Therefore, convergent validity is established.

Table 1. Measurement model

\begin{tabular}{|c|c|c|c|c|}
\hline Construct & Item & Loading & AVE & CR \\
\hline \multirow[t]{5}{*}{ Loyalty Intention (LI) } & LI2 & 0.821 & \multirow[t]{5}{*}{0.709} & \multirow[t]{5}{*}{0.924} \\
\hline & LI3 & 0.853 & & \\
\hline & LI4 & 0.803 & & \\
\hline & LI5 & 0.834 & & \\
\hline & LI6 & 0.895 & & \\
\hline \multirow[t]{7}{*}{ Perceived Ease of Use (PEU) } & PEU1 & 0.854 & \multirow[t]{7}{*}{0.613} & \multirow[t]{7}{*}{0.917} \\
\hline & PEU2 & 0.765 & & \\
\hline & PEU3 & 0.758 & & \\
\hline & PEU4 & 0.755 & & \\
\hline & PEU5 & 0.835 & & \\
\hline & PEU6 & 0.751 & & \\
\hline & PEU7 & 0.757 & & \\
\hline \multirow[t]{4}{*}{ Perceived Usefulness (PU) } & PU1 & 0.853 & \multirow[t]{4}{*}{0.632} & \multirow[t]{4}{*}{0.872} \\
\hline & PU2 & 0.731 & & \\
\hline & PU3 & 0.825 & & \\
\hline & PU4 & 0.765 & & \\
\hline \multirow[t]{4}{*}{ Website Design Quality (WDQ) } & WDQ1 & 0.835 & \multirow[t]{4}{*}{0.729} & \multirow[t]{4}{*}{0.915} \\
\hline & WDQ2 & 0.871 & & \\
\hline & WDQ3 & 0.844 & & \\
\hline & WDQ4 & 0.865 & & \\
\hline
\end{tabular}

Note: $\mathrm{AVE}=$ Average Variance Extracted, $\mathrm{CR}=$ Composite Reliability 
Table 2 shows the test results for discriminant validity. Following Fornell and Larcker (2016), the AVE of each construct should be higher than the correlation between it and any other constructs in the model. Since all constructs meet this criterion, the discriminant validity is achieved.

Table 2. Discriminant validity (Fornell-Larcker Criterion)

\begin{tabular}{|c|c|c|c|c|}
\hline Construct & LI & PEU & PU & WDQ \\
\hline Loyalty Intention (LI) & 0.842 & & & \\
\hline Perceived Ease of Use (PEU) & 0.747 & 0.783 & & \\
\hline Perceived Usefulness (PU) & 0.574 & 0.746 & 0.795 & \\
\hline Website Design Quality (WDQ) & 0.702 & 0.740 & 0.517 & 0.854 \\
\hline
\end{tabular}

Note: Values in the diagonal are AVEs while the off-diagonals are squared correlations

Another test of discriminant validity is cross loadings (Hair et al., 2017). The scholars suggested that the loadings of each item (measured variables) should be higher than the cross loadings by at least 0.1 . The study results show that the loadings of all constructs satisfy this criterion (Table 3). As such, we can conclude that discriminant validity is established.

Table 3. Discriminant validity (cross loadings)

\begin{tabular}{|c|c|c|c|c|}
\hline Item & LI & PEU & PU & WDQ \\
\hline LI2 & 0.821 & 0.603 & 0.441 & 0.582 \\
\hline LI3 & 0.853 & 0.686 & 0.541 & 0.675 \\
\hline LI4 & 0.803 & 0.553 & 0.435 & 0.586 \\
\hline LI5 & 0.834 & 0.648 & 0.481 & 0.531 \\
\hline LI6 & 0.895 & 0.641 & 0.507 & 0.570 \\
\hline PEU1 & 0.592 & 0.854 & 0.666 & 0.647 \\
\hline PEU2 & 0.613 & 0.765 & 0.651 & 0.564 \\
\hline PEU3 & 0.508 & 0.758 & 0.554 & 0.511 \\
\hline PEU4 & 0.458 & 0.755 & 0.560 & 0.578 \\
\hline PEU5 & 0.599 & 0.835 & 0.606 & 0.662 \\
\hline PEU6 & 0.627 & 0.751 & 0.530 & 0.482 \\
\hline PEU7 & 0.670 & 0.757 & 0.516 & 0.594 \\
\hline PU1 & 0.480 & 0.691 & 0.853 & 0.482 \\
\hline PU2 & 0.464 & 0.508 & 0.731 & 0.373 \\
\hline PU3 & 0.488 & 0.596 & 0.825 & 0.440 \\
\hline PU4 & 0.381 & 0.565 & 0.765 & 0.330 \\
\hline WDQ1 & 0.597 & 0.563 & 0.399 & 0.835 \\
\hline
\end{tabular}




\begin{tabular}{|c|c|c|c|c|}
\hline WDQ2 & 0.618 & 0.629 & 0.429 & 0.871 \\
\hline WDQ3 & 0.629 & 0.652 & 0.448 & 0.844 \\
\hline WDQ4 & 0.553 & 0.678 & 0.486 & 0.865 \\
\hline
\end{tabular}

\section{Structural Model Estimation}

The structural model estimation was carried out following bootstrapping procedure (Hair et al., 2017). To determine the t-values, 5,000 resamples was run. Figure 1 shows the result of structural model estimation, while Table 4 presents the results of the hypothesis testing. There is a positive relationship between Website Design Quality (WDQ) and Loyalty Intention $(\beta=0.334, p<0.01)$, Perceived Ease of Use (PEU) $(\beta=0.740, p<0.001)$ and Perceived Usefulness (PU) $(\beta=0.517, p<0.001)$. While, the influence of PEU on LI is significantly positive $(\beta=0.451, p<0.001)$, the influence of PU on LI is not significant $(\beta=0.065$, t-value $=0.726)$. The $\mathrm{R} 2$ values suggest that WDQ explains $54.8 \%$ variance in PEU and $26.7 \%$ variance in PU. Finally, all the three independent variables (WDQ, PEU and PU) explain $60.8 \%$ variance in LI. Hence, except for hypothesis 5, all other hypotheses are supported.

Table 4. Results of the hypotheses testing

\begin{tabular}{|c|c|c|c|c|c|}
\hline Hypotheses & Relationship & Std. Beta & Std. Error & t-Value & Decision \\
\hline H1 & WDQ $\rightarrow$ LI & 0.334 & 0.125 & $2.722^{* *}$ & Supported \\
\hline H2 & WDQ $\rightarrow$ PEU & 0.740 & 0.047 & $15.525^{* * *}$ & Supported \\
\hline H3 & WDQ $\rightarrow$ PU & 0.517 & 0.090 & $5.661^{* * *}$ & Supported \\
\hline H4 & PEU $\rightarrow$ LI & 0.451 & 0.114 & $3.979 * * *$ & Supported \\
\hline H5 & PU $\rightarrow$ LI & 0.065 & 0.089 & 0.726 & Not supported \\
\hline
\end{tabular}

Note: $* \mathrm{p}<0.05,{ }^{* *} \mathrm{p}<0.01, * * * \mathrm{p}<0.001$ 


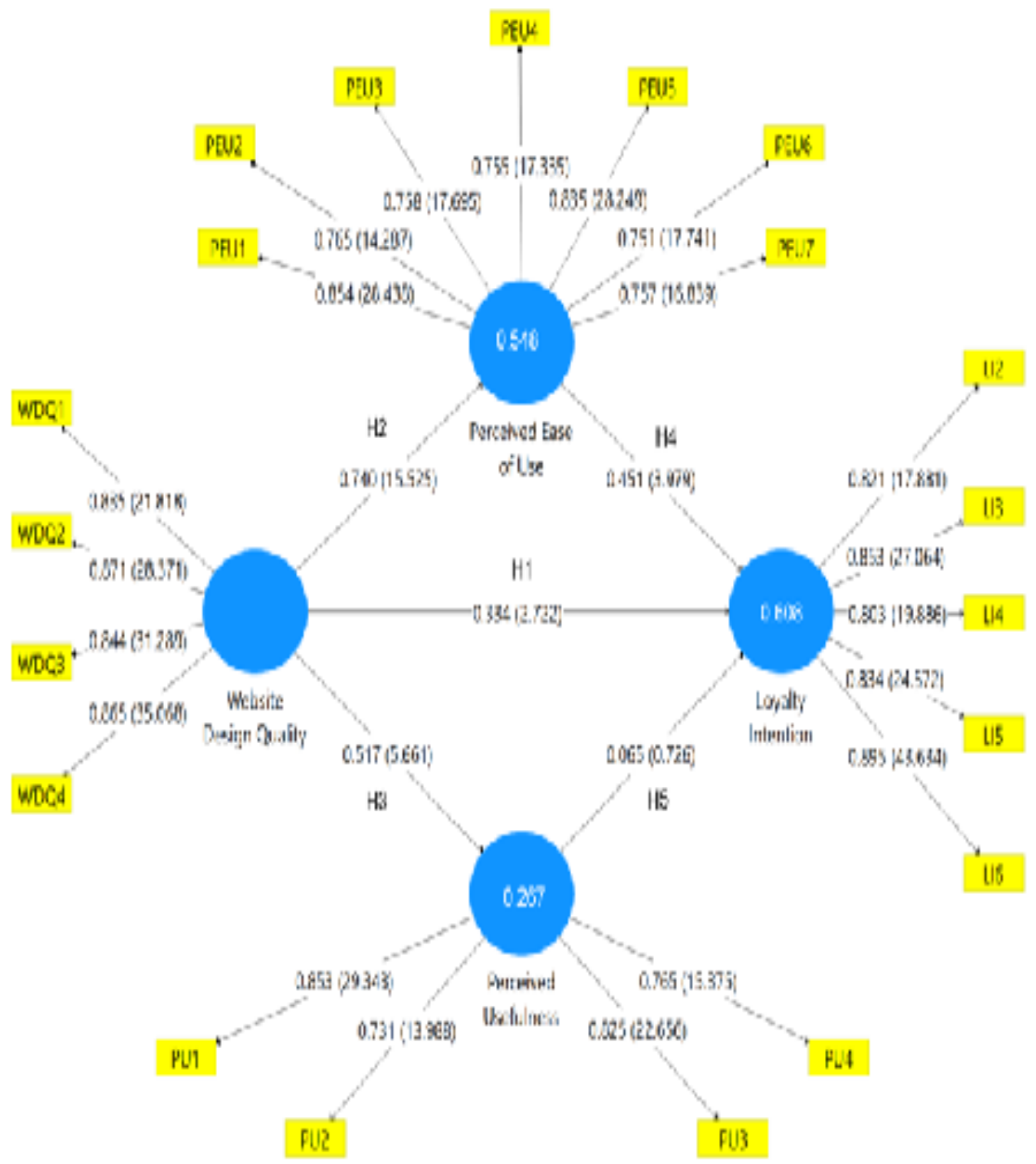

Figure 1. Results of the structural model estimation

\section{CONCLUSION}

Results from SmartPLS analysis shows that four out of five hypotheses (H1, H2, H3 and H4) were supported. WDQ was found to have a positive influence on LI. This finding was in line with the results of a study carried out by Kim and Niehm (2009), which showed that website quality of apparel retailers is important in influencing customers loyalty to their stores. 
The website design quality is vital to enable online customers to be able to access for information conveniently, share the information among other website users and to adapt instantly to any changes in market environment. Therefore, hoteliers need to work hand in hand with professional website developers in developing and maintaining their official hotel booking website. Thus, their hotel websites will be useful and beneficial to website users. Consequently, it promotes customer loyalty.

The results of the analysis also revealed that WDQ has a positive influence on PEU and PU. This finding supports the work of Zhou (2011), which has also found that the quality of mobile website is the main factor affecting perceived ease of use and perceived usefulness. Proper design of business website is necessary to ensure customers usage requirements and preferences are met. The websites need to be fully functional, easy to access, updated, informative, responsive and interactive to encourage adoption among business customers. Therefore, hotel website must be design carefully to make it useful and convenient for customers to search for information and perform online transaction.

While, the result shows that PEU has a positive influence on LI (H4 is supported), surprisingly the present research found that the influence of PU on LI is not significant (H5 is not supported). Since the present study did not differentiate the results by examining response provided by highly experienced and less experienced website users, the justification behind this expected result may not be conclusive. Hence, it is recommended for future researchers to include users Internet experience or users' technology readiness as moderating variable in their future studies.

\section{ACKNOWLEDGEMENTS}

This project has been funded by the Ministry of Higher Education of Malaysia (MOHE) under the Fundamental Research Grant Scheme (FRGS) (Reference No: FRGS/1/2017/SS01/UITM/03/08) through Universiti Teknologi MARA (UiTM) (Reference No: 600-IRMI/FRGS 5/3 (061/2017).

\section{REFERENCES}

Abdullah, D., Jayaraman, K., \& Kamal, S. B. M. (2016). A conceptual model of interactive hotel website: The role of perceived website interactivity and customer perceived value toward website revisit intention. Procedia Economics and Finance, 37, 170-175.

Abdullah, D., Jayaraman, K., Shariff, D. N., Bahari, K. A., \& Nor, N. M. (2017). The effects of perceived interactivity, perceived ease of use and perceived usefulness on online hotel booking intention: A conceptual framework. International Academic Research Journal of Social Science, 3(1), 16-23.

Akincilar, A., \& Dagdeviren, M. (2014). A hybrid multi-criteria decision making model to evaluate hotel websites. International Journal of Hospitality Management, 36, 263-271.

Anderson, R. E., \& Srinivasan, S. S. (2003). E-satisfaction and e-loyalty: A contingency framework. Psychology and Marketing, 20(2), 123-138.

Bhatiasevi, V., \& Yoopetch, C. (2015). The determinants of intention to use electronic booking among young users in Thailand. Journal of Hospitality and Tourism Management, 23, 1-11.

Carlson Wagonlit Travel. (2011). Business traveler services: Finding the right fit. Carlson Wagonlit Travel.

Chirico, P., \& Presti, A. L. (2008). A customer loyalty model for services based on a continuing relationship with the provider. Methods, Models and Information Technologies for Decision Support Systems, 1(1), 168-171.

Collier, J. E., \& Bienstock, C. C. (2006). Measuring service quality in e-retailing. Journal of Service Research, 8(3), 260-275.

Davis, F. D. (1989). Perceived usefulness, perceived ease of use, and user acceptance of information technology. MIS Quarterly, 13(3), 319-340.

Diaz, E., \& Koutra, C. (2013). Evaluation of the persuasive features of hotel chains websites: A latent class segmentation analysis. International Journal of Hospitality Management, 34(1), 338-347.

Fornell, C., \& Larcker, D. F. (2016). Evaluating structural equation models with unobservable variables and measurement Error. Journal of Marketing Research, 18(1), 39-50.

$H a, Y ., \& I m, H$. (2012). Role of web site design quality in satisfaction and word of mouth generation. Journal of Service Management, 23(1), 79-96. 
Hahn, K. H., \& Kim, J. (2009). The effect of offline brand trust and perceived internet confidence on online shopping intention in the integrated multi-channel context. International Journal of Retail and Distribution Management, 37(2), 126-141.

Hair, J. F., Hult, G. T. M., Ringle, C. M., \& Sarstedt, M. (2017). A primer on partial least squares structural equation modeling (PLS-SEM). SAGE Publications.

Herrero, A., \& San Martín, H. (2012). Developing and testing a global model to explain the adoption of websites by users in rural tourism accommodations. International Journal of Hospitality Management, 31(4), 1178-1186.

Kim, H., \& Niehm, L. S. (2009). The impact of website quality on information quality, value, and loyalty intentions in apparel retailing. Journal of Interactive Marketing, 23(3), 221-233.

Koufaris, M. (2002). Applying the technology acceptance model and flow theory to online consumer behavior. Information Systems Research, 13(2), 205-223.

$K u, E$. C. S., \& Chen, C.-D. (2015). Cultivating travellers' revisit intention to e-tourism service: The moderating effect of website interactivity. Behaviour and Information Technology, 34(5), 465-478.

Kucukusta, D., Law, R., Besbes, A., \& Legoherel, P. (2015). Re-examining perceived usefulness and ease of use in online booking: The case of Hong Kong online users. International Journal of Contemporary Hospitality Management, 27(2), 185-198.

Lam, S. Y., Shankar, V., Erramilli, M. K., \& Murthy, B. (2004). Customer value, satisfaction, loyalty, and switching costs: An illustration from a business-to-business service context. Journal of the Academy of Marketing Science, 32(3), 293-311.

Law, R., Qi, S., \& Buhalis, D. (2010). Progress in tourism management: A review of website evaluation in tourism research. Tourism Management, 31(3), 297-313.

Lehto, X. Y., Brown, S., Chen, Y. I., \& Morrison, A. M. (2006). Yoga tourism as a niche within the wellness tourism market. Tourism Recreation Research, 31(1), 25-35.

Li, L., Peng, M., Jiang, N., \& Law, R. (2017). An empirical study on the influence of economy hotel website quality on online booking intentions. International Journal of Hospitality Management, 63, 110 .

McMullan, R., \& Gilmore, A. (2008). Customer loyalty: An empirical study. European Journal of Marketing, 42(9/10), 1084-1094.

Mou, J., Shin, D.-H., \& Cohen, J. (2016). Understanding trust and perceived usefulness in the consumer acceptance of an e-service: A longitudinal investigation. Behaviour and Information Technology, 36(2), 125-139.

Oliver, R. L., Rust, R. T., \& Varki, S. (1997). Customer delight: Foundations, findings, and managerial insight. Journal of Retailing, 73(3), 311-336.

Pai, F.-Y., \& Yeh, T.-M. (2014). The effects of information sharing and interactivity on the intention to use social networking websites. Quality and Quantity, 48(4), 2191-2207.

Parasuraman, A., Zeithaml, V. A., \& Malhotra, A. (2005). E-S-QUAL: A multiple-item scale for assessing electronic service quality. Journal of Service Research, 7, 1-21.

Rodzi, F. N. A., Nasir, E. A. M., Azmi, A. L. M., Abdullah, D., Azmi, A., \& Kamal, S. B. M. (2016). The role of compatibility, information quality and e-service quality in predicting mobile hotel booking adoption: A conceptual framework. International Academic Research Journal of Business and Technology, 2(2), 123-128.

Rosli, N. H. M., Jamil, S. N. A., Kamal, S. B. M., Abdullah, D., \& Azmi, A. (2016). Consumers intention to use smartphone while travelling and its impact on loyalty. International Academic Research Journal of Business and Technology, 2(2), 107-111.

Sabiote, C. M., Frías, D. M., \& Castañeda, J. A. (2012). E-service quality as antecedent to esatisfaction: The moderating effect of culture. Online Information Review, 36(2), 157-174.

Theofanos, M., \& Mulligan, C. (2004). Empowering Patients through access to information. Information Communication Society, 7(4), 466-490.

Tsai, H. T., Huang, L., \& Lin, C. G. (2005). Emerging e-commerce development model for Taiwanese travel agencies. Tourism Management, 26(5), 787-796. 
The Turkish Online Journal of Design, Art and Communication - TOJDAC

ISSN: 2146-5193, September 2018 Special Edition, p.701-710

Wakefield, R. J., Stocks, M. H., \& Wilder, W. M. (2004). The role of web site characteristics in initial trust formation. Journal of Computer Information Systems, 45(1), 94-103.

Yang, C. C., Chu, K. H., \& Yang, Y. W. (2006). $3 G$ and WLAN interworking security: Current status and key issues. International Journal of Network Security, 2(1), 1-13.

Zhou, T. (2011). Examining the critical success factors of mobile website adoption. Online Information Review, 35(4), 636-652. 